\title{
Population Dynamics of the Black Tinder Fungus Beetle Bolitophagus reticulatus
}

\author{
Monika LIK \\ Accepted November 4, 2005

\begin{abstract}
LIK M. 2005. Population dynamics of the black tinder fungus beetle Bolitophagus reticulatus. Folia biol. (Kraków) 53 (Suppl.): 171-177.

The aim of the study was to describe seasonal changes in numbers and settlement of basidiocarps of tinder fungus [Fomes fomentarius (L. ex Fr.) Kick] by the coleopteran Bolitophagus reticulatus L. in relation to the weight and the stage of decomposition of a basidiocarp in different types of forest habitats. Tinder fungi, which contained the coleopterans, were collected from four sample plots located in the Tuchola Forest and the Myśleccinek area located within the administrative borders of the town of Bydgoszcz. Out of 763 collected tinder fungus basidiocarps, the coleopteran B. reticulatus inhabited 322 , from which 2643 imagines and 685 larvae were obtained. In each of the studied habitats noticeable concentrations of coleopterans in dead basidiocarps of tinder fungus were observed. Differences in settlement of living and dead fruiting bodies proved statistically significant. Irrespective of the sample plot where the fungi were collected, the number and settlement of tinder fungus basidiocarps by $B$. reticulatus changed within a year, reaching highest values in winter. The influence of the season on values describing settlement of basidiocarps by $B$ reticulatus was confirmed statistically. No statistically significant influence of the forest habitat type and the weight of basidiocarps on settlement of tinder fungus by B. reticulatus were revealed.
\end{abstract}

Key words: Bolitophagus reticulatus, tinder fungus, Fomes fomentarisus, saproxylic species.

Monika LIK, Department of Zoology, University of Technology and Agriculture, Kordeckiego 20, 85-225 Bydgoszcz, Poland.

E-mail:molik@atr.bydgoszcz.pl

The majority of woodland areas in Poland are covered by managed forests, strongly transformed by human activity. Their main function is wood production. It is due to the age structure of these tree stands and applied methods of forest management that large decaying dead tree trunks are rare in Polish forests. The habitat of dead wood is among the most endangered biotopes in Europe. At present, organisms associated with this habitat can be treated as indicators of the level of naturalness of forest ecosystems, as saproxylic species occur only in places that provide a continuous food supply and development base (GUTOWSKI et al. 2004).

Beetles (Coleoptera) are one of the insect groups most numerously represented by saproxylic forms. Nearly a half of seven thousand species of beetles occurring in Central Europe can be found in dead wood (BUCHHOLZ \& OSSOWSKA 1995). In Poland saproxylic species represent about 70 families from this order of insects (GUTOWSKI \& BUCHHOLZ 2000).

Despite increasing interest in saproxylic fauna (BUCHHOLZ \& OSSOWSKA 1995; BURAKOWSKI
1997; GUTOWSKI \& BUCHHOLZ 2000; BOROWSKI 2000 etc.), detailed ecological studies on this group of insects are lacking in Poland.

The aim of the study was to define seasonal changes in numbers and settlement of saproxylic beetles Bolitophagus reticulatus L. in basidiocarps of tinder fungus [Fomes fomentarius (L. ex Fr.) Kick] in relation to the weight and the stage of decomposition of basidiocarps in different types of forest habitats.

\section{Material and Methods}

Basidiocarps of tinder fungus were collected from fallen, rotten trunks of the common birch (Betula verrucosa L.) in autumn and winter 1996 and spring and summer 1997. Fungi were collected from four sample plots located in the Tuchola Forest - two nature reserves "Cisy Staropolskie to name after L. Wyczółkowski" in Wierzchlas and "Brzęki to name after Prof. Z. Czubiński", in the region of Biała near Woziwoda, from the 


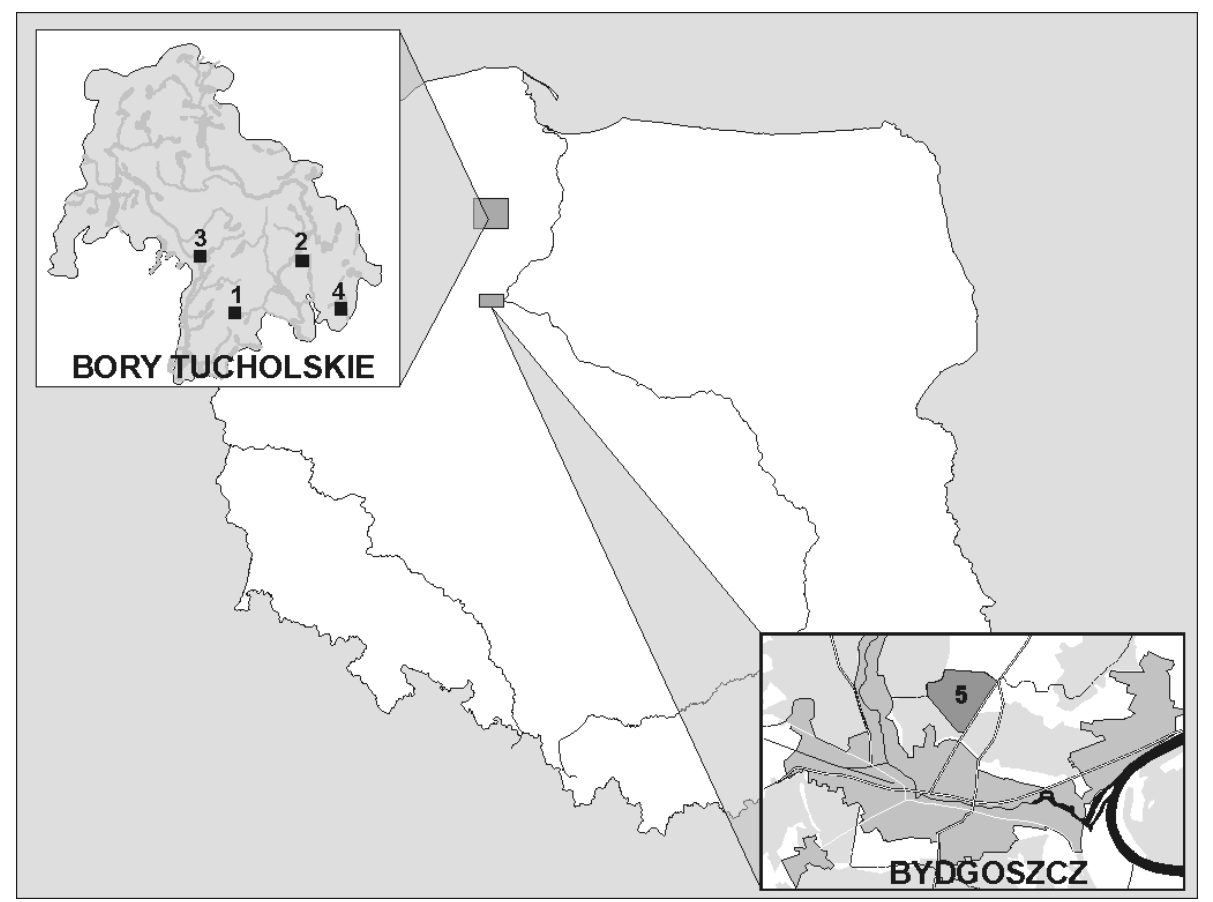

Fig. 1. Location of sample plots. Legend: 1 -“Cisy Staropolskie”; 2 -"Brzęki”; 3 - Biała; 4 - Rulewo; 5 - Myślęcinek.

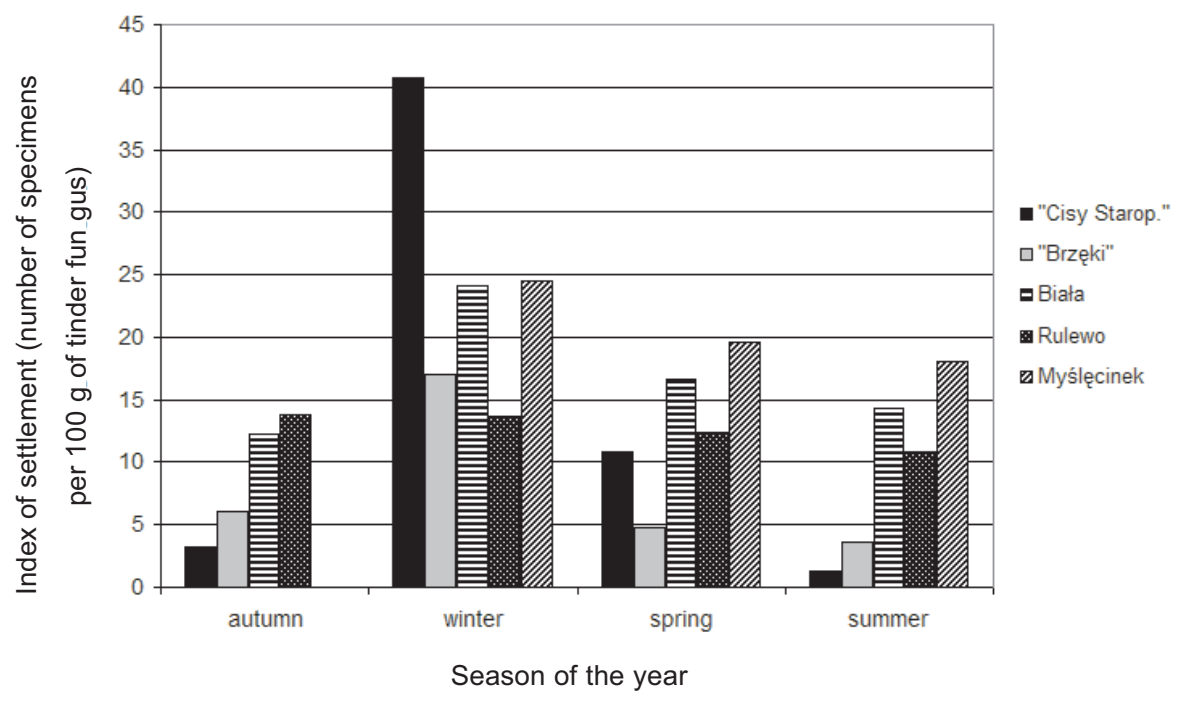

Fig. 2. Seasonal population dynamics of the black tinder fungus beetle Bolitophagus reticulatus.

forest near Rulewo village and the Myślęcinek area, located in the suburban zone of Bydgoszcz (Fig. 1).

Each sample plot represented a different type of forest habitat: Myślęcinek - subcontinental fresh coniferous forest (Peucedano-Pinetum), nature reserve "Cisy Staropolskie" - subcontinental dryground forest (Tilio cordate-Carpinetum betuli), nature reserve "Brzęki" - lowland oak-hornbeam forest (Stellario holosteae-Carpinetum betuli), forests near Rulewo - suboceanic fresh coniferous forest (Leucobryo-Pinetum), and a patch of mixed woodland on a wetland near Biała village was de- fined as "transformed carr" considering specific species of its undergrowth.

The selected plots represented various stages of transformation by human activity. The most changed habitats were managed forests - pine monocultures in Rulewo and Myślęcinek. "Transformed carr" in Biała was a small fertile forest enclave, excluded from forest management and surrounded by production forests. Two remaining plots were covered by nearly natural forests, such as partially protected nature reserve "Brzęki" or strictly protected "Cisy Staropolskie" reserve - the oldest reserve in Poland, protected since 1827, 
with the largest concentration of yew trees in Central Europe (CONVENTZ 1892).

In total, 763 specimens of tinder fungus were collected from all sample plots. B. reticulatus inhabited 322 basidiocarps, including 90 live and 232 dead fungi (Table 1). Fungi obtained from the described habitats were divided into two groups living (hard, with no signs of decomposition) and dead basidiocarps (fragile, with visible signs of occupation by mycophagous organisms).

Next, fungi were put into glass jars, covered with gauze and left in a warm and dry place for the purpose of raising and isolating insects from them. Beetles leaving basidiocarps were systematically collected and conserved in a $70 \%$ solution of ethyl alcohol. To ensure that all insects that inhabited basidiocarps were found, fungi were fragmented and the remaining beetle specimens were collected. After the insects had been isolated and water had evaporated, basidiocarps of tinder fungus were weighed and divided into three classes: up to $50 \mathrm{~g}$ (class I), from 50 to $100 \mathrm{~g}$ (class II) and over 100 g (class III) - Table 1.

To unify the obtained values, they were recalculated into $100 \mathrm{~g}$ of a basidiocarp of tinder fungus (index of settlement) which allowed for elimination of a potential bias caused by uneven samples or the size of basidiocarps. To define the statistical significance of differences in settlement of tinder fungus basidiocarps by the beetles, nonparametric tests were applied - the Kruskal-Wallis test as an equivalent of the analysis of variance or MannWhitney U-test - an equivalent of Student's $t$-test; significance level $\mathrm{P} \leq 0.05$ was accepted.

\section{Results}

In total 2643 imagines and 685 larvae of $B$. reticulatus were obtained (Table 2). Settlement of basidiocarps by coleopterans (excluding larvae) was at the level of almost 13 specimens per $100 \mathrm{~g}$ of fungus and was slightly over 8 insects per single basidiocarp of tinder fungus (Table 2).

Almost two times more specimens of Bolitophagus reticulatus were isolated from dead basidiocarps (1935), with a higher index of settlement (14.33 specimens/100 $\mathrm{g}$ fungus) than from living ones and higher number of beetles in a single dead basidiocarp (8.34 specimens) - Table 2. Differences in settlement of living and dead basidiocarps proved statistically significant $(\mathrm{U}=1, \mathrm{P}<0.001)$.

During a year settlement of basidiocarps by the beetles reached the highest level in the winter (Fig. 2), both in the case of dead (18.78/100 $\mathrm{g}$ of fungus) and living fungi (19.71/100 g of fungus) (Table 2). Also a higher number of coleopterans was ob- tained from basidiocarps collected during winter (938 specimens) than in the remaining seasons (Table 2). The influence of the seasons on the index of settlement of basidiocarps by B. reticulatus was statistically significant $(\mathrm{H}=9.834285, \mathrm{df}=3$, $\mathrm{n}=20, \mathrm{P}=0.02$ ).

B. reticulatus was most abundant in basidiocarps originating from the habitat of the "transformed carr" in Biała (959 specimens) (Table 2). However, the highest settlement (20.4 specimens/100 g of tinder fungus) with the lowest number of collected specimens (210 beetles), was observed in the case of fungi collected in Myślęcinek (habitat Peucedano-Pinetum) (Table 2). Despite these differences, no statistically significant influence of the forest habitat type on settlement of basidiocarps of tinder fungus by $B$. reticulates was revealed $(\mathrm{H}=3.142857, \mathrm{df}=4, \mathrm{n}=20, \mathrm{P}=0.5342)$.

In the weight comparisons, basidiocarps which reached up to $50 \mathrm{~g}$ were characterized by higher settlement irrespective of the stage of decomposition of the tinder fungus (Table 2). However, differences in the level of settlement among basidiocarps of different weight did not prove statistically significant $(\mathrm{H}=2.179999, \mathrm{df}=2, \mathrm{n}=15$, $\mathrm{P}=0.3362$ ).

The number of specimens of $B$. reticulatus found in basidiocarps from subsequent weight groups differed between living and dead fungi. In the case of living basidiocarps most beetles were found in tinder fungi reaching up to $50 \mathrm{~g}$ (371 specimens), while in dead sporophores they were most numerous in the heaviest fungi (992 specimens)-Table 2.

In total 685 larvae of B. reticulatus were obtained from the collected basidiocarps, the majority came from the "transformed carr" in Biała (442 specimens), similarly as in the case of imagines. Larvae inhabited dead basidiocarps more numerously, especially those heavier than $100 \mathrm{~g}$ (Table 2).

\section{Discussion}

Comparisons of the obtained results with existing data on fauna of mycophagous insects is difficult due to different methods used by various authors (e.g. KAILA et al. 1994; THUNES 1994; ØKLAND 1995; JONSSELL \& NORDLANDER 2002; BOROWSKI 2001). In many studies only the total number of invertebrates isolated from fungi is given, not recalculated into any unit of weight or volume, data on the weight and number of basidiocarps covered with the study are often lacking, which impedes any quantitative comparisons (e.g. KAILA et al. 1994; KULA et al. 1999; BOROWSKI 2001). Most authors, irrespective of the methods used, emphasize the presence and even domination of B. reticula- 


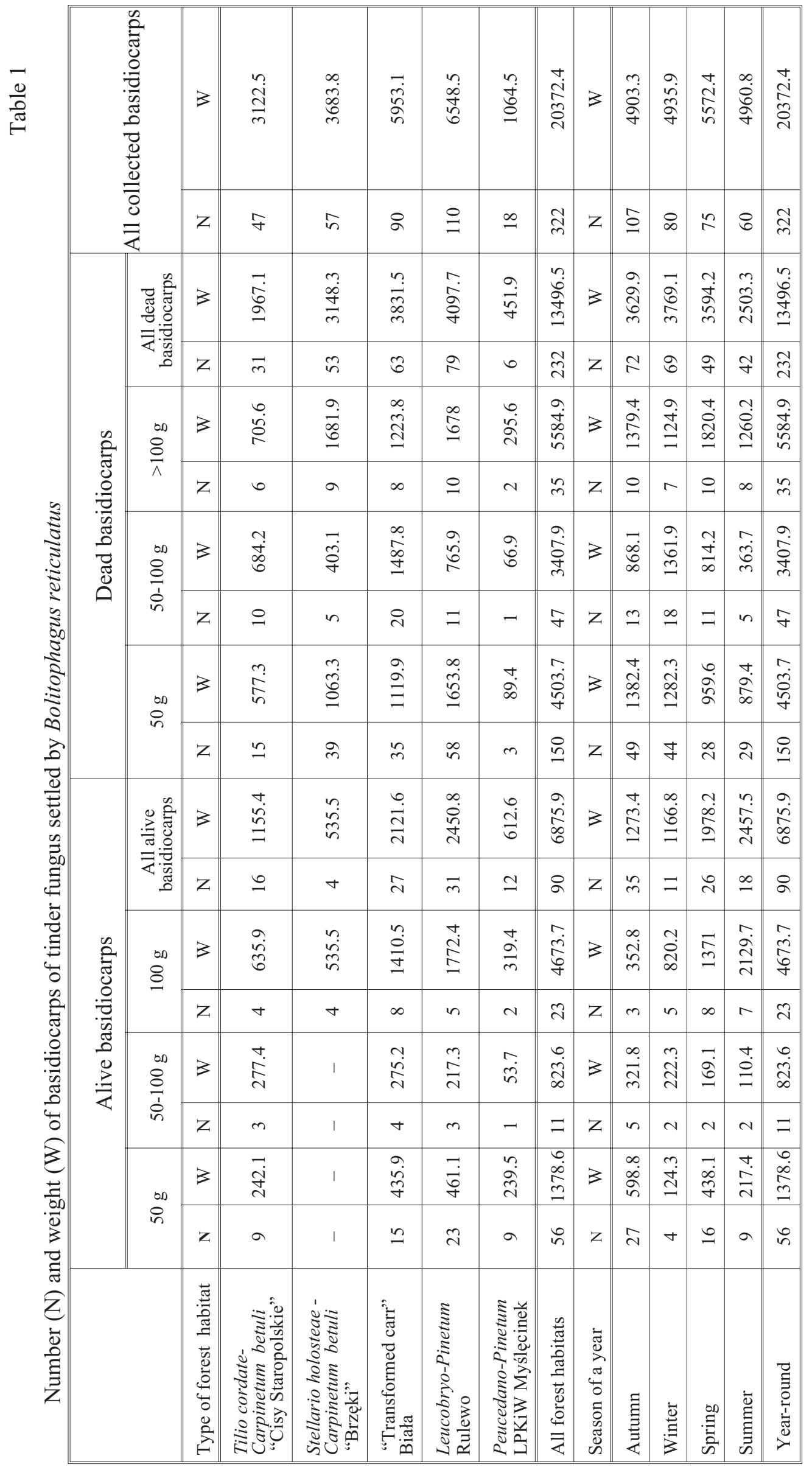




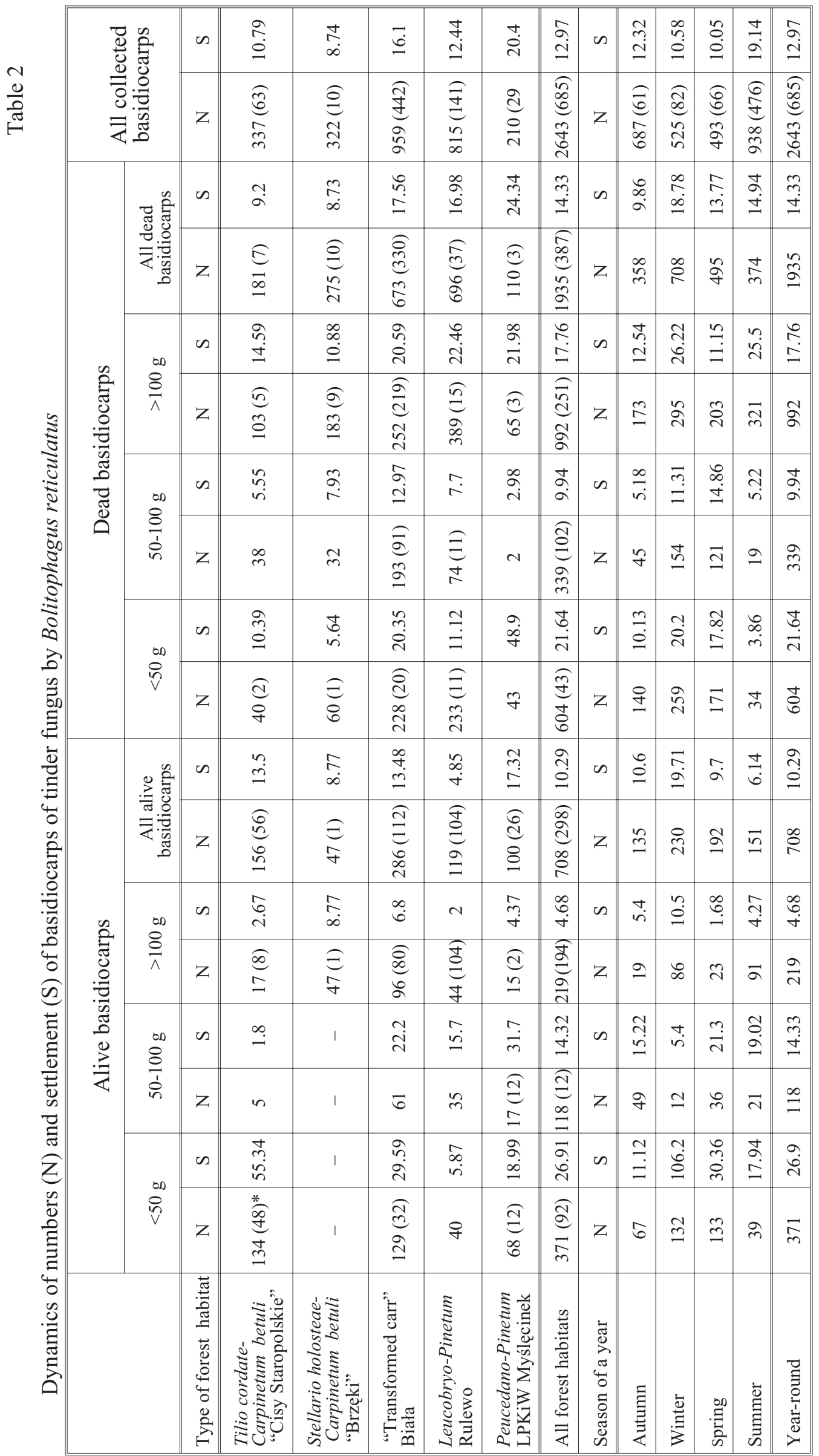


tus in mycophagous insect assemblies, especially those inhabiting basidiocarps of tinder fungus (OSTROWSKI 1965; KAILA et al. 1994; KULA et al. 1999; ØKLAND 1995; KRASUCKIJ 1997; LIK 2001 etc.).

Imagines and larvae of $B$. reticulatus settle mainly in dead basidiocarps of fungi and by excavating tunnels inside they cause the destruction of the basidiocarp (NADVORNAYA \& NADVORNY 1991). Volatile substances excreted by dead basidiocarps of fungi are characterized by the presence of such substances as ethanol and acetic acid, which act as attractants for many insect species reproducing in sporophores (FÄLDT et al. 1999). Thus, a higher number of imagines and larvae of $B$. reticulatus obtained from dead basidiocarps of tinder fungus is not surprising, especially that this preference was supported by other studies (MIDTGAARD et al. 1998; KULA et al. 1999; JONSELL et al. 2003). In the present study numerous beetles were also found in living fungi, which could result from the method used to procure them. The collected material, as in similar studies, was divided into two categories - living and dead tinder fungi (NILSSON 1997 a, b; MIDTGAARD et al. 1998; CINKIEWICZ 1999 etc.). However, GRAVES (1960) distinguished as much as five development stages of basidiocarps: I-II for living basidiocarps, III-V for dead ones. Apparently even basidiocarps at the second stage can be colonized by insects as some parts of the fungus tissues already undergo decay, hence the occurrence of coleopterans in the group of living basidiocarps. In the natural environment beetles were observed also on the pore layer surface of living basidiocarps. A plausible explanation is that living basidiocarps or the spores they produce are richer than dead ones in nutrients essential for the reproduction of these insects (NILSSON $1997 \mathrm{a}, \mathrm{b}$ ).

In contrast with imagines, larvae develop only in dead tissues of fungi (NILSSON $1997 \mathrm{~b}$ ), and the fact that they were collected from living basidiocarps suggests that at last some of the tinder fungi classified as "living" was already at the second stage of decomposition.

Despite a lack of statistical significance of differences in settlement of $B$. reticulatus in basidiocarps of tinder fungus of various weight, this phenomenon seems interesting against the background of available publications.

Most authors dealing with the issue of influence of basidiocarp size on mycophagous insects agree that invertebrates prefer large basidiocarps due to higher stability of such microenvironments, longer time available for their colonization, and greater amount of attractive odour excreted (NILSSON 1997b; O'CONNEL \& BOLGER 1998; RUKKE \& MIDTGAARD 1998; MidTGAARD et al. 1998; RUKKE 2000). These observations are supported by the presented results as $B$. reticulatus was most abundant in the heaviest basidiocarps (1211 specimens - Table 2). However, considering the index of settlement of fungi by $B$. reticulates, an opposite phenomenon was observed than in the abundance analysis, i.e. a higher index of settlement in the case of basidiocarps reaching a weight up to $50 \mathrm{~g}$ both in living and dead tinder fungi.

Probably it is easier for these insects to 'acquire' a small basidiocarp, as in a fungus of limited dimensions the number of specimens in relation to its size or volume increases more rapidly than in a large one. After colonization of a new basidiocarp, insects reproduce quickly until they use up the food base and the fungus is 'rotten'. In the case of small tinder fungi, their decomposition is quicker and more decayed basidiocarps offer more diverse food substratum than living and hard specimens. Hence, the highest index of settlement by $B$. reticulatus was noted in the case of dead tinder fungi of a weight up to $50 \mathrm{~g}$ (Table 2).

Seasonal factors also significantly affected settlement of basidiocarps of tinder fungus by $B$. reticulatus. The winter increase of the index of settlement could be caused by the occurrence of a new generation of coleopterans in basidiocarps. Development of this species lasts for 7-12 months if eggs are laid in early spring (NADVORNAYA \& NADVORNY 1991), thus the increase of settlement is observed at the end of the year, when new generations of insects leave pupae. In the case of postponed egg laying, larvae overwinter and their development finishes in the spring of the following year (NADVORNAYA \& NADVORNY 1991).

Among available Polish literature on assemblies of insects associated with tree fungi, only BOROWSKI (2001) referred to the problem of influence of the habitat type on fauna of mycophagous insects, comparing forest communities of the forest district Hajnówka and the Bialowieża National Park (BPN). In the first case (Hajnówka) most specimens were collected from the most fertile habitats, while in the second (BPN) most abundant collections came from poorer coniferous forest habitats. Thus, preferences of mycophagous insects to certain types of forest habitat cannot be unambiguously confirmed. The main factor that influences the abundance of fungivorous insects is the presence of dead wood on a given sample plot (BUCHHOLZ et al. 2000). As soon as dead tree trunks appear in any habitat they are colonized by fungi, followed by mycophagous fauna, which is confirmed by the presented results. Even in suburban forests, such as fresh coniferous forest (Peucedano-Pinetum) in Myślęcinek, as soon as favourable conditions for development of tinder fungi occurred, beetles reproduced intensively as well. In effect basidiocarps obtained from this 
habitat had the highest index of settlement by this mycophagous species. Thus, it seems that habitat can indirectly influence the numbers and settlement of fungi by fungivorous organisms by shaping some features of basidiocarps (such as the stage of decomposition, weight, size, water content etc.) so that they become more available for invertebrates that feed on them (MIDTGAARD et al. 1998).

Despite advancement of degradation of environment and gradual transformation of forest ecosystems into production tree stands, the abundance of saproxylic forms (including mycophags) can be preserved easily by leaving even a small amount of dead wood, which is the main condition needed for development of various species of tree Polyporaceae irrespective of the forest habitat. It has been calculated that even $5-10 \mathrm{~m}^{3} /$ ha of dead wood substrate provides sufficient food and development base for the majority of saproxylic insects (GUTOWSKI \& BUCHHOLZ 2000; SITTONEN 1994).

\section{Conclusions}

- The study demonstrated that the abundance and index of settlement (specimens per $100 \mathrm{~g}$ of tinder fungus) of $B$. reticulatus colonizing fruiting bodies of tinder fungus depended on the season of the year. The influence of the season on index of settlement of basidiocarps by B. reticulatus was statistically significant.

- In each of the studied habitats noticeable concentrations of $B$. reticulatus in dead basidiocarps of tinder fungus were observed. Differences in settlement of living and dead fruiting bodies proved statistically significant.

- No statistically significant influence of the forest habitat type and the weight of basidiocarps on settlement of tinder fungus by $B$. reticulatus were revealed.

\section{References}

BOROWSKI J. 2001. The valorization attempts of Białowieża forest on the basis of the beetles (Coleoptera) inhabiting bracket fungi. (In: The Estimated Valorization Attempts of Białowieża Forest by Using Zooindicative Method. A. Szujecki ed. SGGW, Warszawa): 287-318.

BUCHHOLZ J., OSSOWSKA M. 1995. Entomofauna of dead wood - its biocenotic meaning in forest environments and possibilities and problems in it's protection. Przegląd Przyrodniczy (Swiebodzin) 6: 93-105. (In Polish).

BuchHolz L., Kubisz D., GuTOWSKi J. M. 2000. Protection of beetles (Coleoptera) in Poland - problems and possible solutions. Wiad. Ent. (Poznań) 18:155-163.

BURAKOWSKI B. 1997. Observations and remarks on the beetles (Coleoptera) inhabiting rotting wood microhabitats. Wiad. Ent. (Poznań) 15: 197-206. (In Polish).

CONVENTZ H. 1892. Die Eibe in Westpreussen ein aussterbender Waldbaum.
CINKIEWICZ W. 1999. Structural and functional condition of animal diversity of Belorus: lectures of eight scientific, zoological conference. Mińsk. 342-344. (In Russian).

FÄLDT J., JONSELl M., NORDLANDER G., BORG-KARLSON A. K. 1999. Volatiles of bracket fungi Fomes fomentarius and Fomitopsis pinicola and their functions as insect atractants. J. Chemical Ecology 25: 567-590.

GUTOWSKI J. M., BUCHHOLZ L. 2000. Forest insects - threats and proposal of protection. Wiad. Entomol. (Poznań) 18: 43-72. (In Polish).

GUTOWSKi J. M., BOBIEC A., PAWLACZYK P., ZUB K. 2004. The afterlife of a tree. WWF Polska. Warszawa-Hajnówka. (In Polish).

GRAVES R. C. 1960. Ecological observations on the insect and other inhabitant of woody shelf fungi (Basidiomycetes: Polyporacae) in the Chicago area. Ann. Entomol. Soc. Amer. 53: 61-78.

JONSSELL M., NORDLANDER G. 2002. Insect in polypore fungi as indicator species: a comparison between forest sites differing in amounts and continuity of dead wood. Forest Ecology \& Managment 157: 101-118.

JONSSEL M., SCHROEDER M., LARSSON T. 2003. The saproxylic beetle Bolitophagus reticulatus: its frequency in managed forests, attraction to volatiles and flight period. Ecograpy 26: 421-428.

Kaila L., Martikainen P., Punttila P., YakovleV E. 1994. Saproxylic beetles (Coleoptera) on dead birch trunks decayed by different polypore species. Ann. Zool. Fennici 31: 97-107.

KULA E., BOHÁČ J., JELÍNEK J. 1999. Insect fauna of selected polypore fungi on birch stems in northern Bohemia. Miscellània Zoològica 22: 75-85.

KRASSUCKIJ B. V. 1997. Fungivorous Coleoptera inhabiting main wood-destroying fungi in the middle taiga subzone in west Syberia. Entomol. Obozr. 77: 770-776.

LIK M. 2001. Insect fauna of tinder fungus (Fomes fomentarius) in suburban Bydgoszcz area. (In: Biodiversity and Ecology of Animal Populations in Urban Habitats. P. Indykiewicz, T. Barczak, G. Kaczorowski eds. Nice Bydgoszcz): 62-68. (In Polish).

MitdGAARD F., RUKKE A., SVERDRUP-THYGESON A. 1998. Habitat use of the fungivorous beetle Bolitophagus reticulatus (Coleoptera:Tenebrionidae): Effects of basidiocarp size, humidity and competitors. Eur. J. Entomol. 95: 559-570.

NADVORNAYA L. S., NADVORNY V. G. 1991. Biology of the beetles Bolitophagus reticulatus L. and Uloma culinaris L. (Coleoptera, Tenebrionidae) in the forest steppe zone of Ukraina. Rev. Ent. USSR 70: 349-354.

NILSSON T. 1997 a. Spatial population dynamics of the black tinder fungus beetle Bolitophagus reticulatus. Acta Universitatis Upsalensis.

NILSSON T. 1997 b. Survival and habitat preferences of adult Bolitophagus reticulatus. Ecological Entomology 22: 82-89.

O'CONNELL T., BOLGER T. 1997. Fungal fruiting bodies and the structure or fungus micro-arthropod assemblages. Biology and environment: Proc. Royal Irish Academy 97: 249-262.

ØKLAND B.1995. Insect fauna compared between six polypore species in southern Norwegian spruce forest. Fauna norv. B 42: 21-26.

OSTROWSKI F. 1965. Insects inhabiting bracket fungi. Annales UMCS (Lublin) XX: 121-131. (In Polish)

RUKKE B. A., MidTGAARD F. 1998. The importance of scale and spatial variables for the fungivorous beetle Bolitophagus reticulatus (Coleoptera: Tenebrionidae) in a fragmented forest landscape. Ecography 21: 561-572.

RUKKE B. A. 2000. Fungivorous beetles inhabiting Fomes fomentarius basidiocarps are differently influenced by microhabitat variables. The significance of habitat fragmentation, spatial scale and microhabitat variables for dead wood fungi beetles. Ph.D. Thesis, Division of Zoology, Department of Biology, Faculty of Mathematics and Natural Sciences, University of Oslo.

THUNES K. H. 1994. The coleopteran fauna of Piptoporus betulinus and Fomes fomentarius (Aphyllophorales: Polyporaceae) in western Norway. Entomologica Fennica 5: 157-168. 